\title{
Effect of cow dung on soil physical properties, growth and yield of maize (Zea mays) in a tropical Alfisol
}

\author{
Adekiya $\mathrm{AO}^{1 *}$, Ojeniyi $\mathrm{SO}^{2}$, Owonifari $\mathrm{OE}^{2}$ \\ 1. Department of Crop and Soil Sciences, Landmark University, P.M.B. 1001, Omu-Aran, Kwara State, Nigeria. \\ 2. Department of Crop, soil and Pest management, Federal University of Technology, Akure, Ondo State, Nigeria \\ *Corresponding author email:adekiya2009@yahoo.com
}

\section{Paper Information \\ Received: 19 January, 2016}

Accepted: 12 March, 2016

Published: 1 June, 2016

\begin{abstract}
A B S T R A C T
Field experiments were carried out during the early cropping seasons of 2014 and 2015 at the Teaching and Research Farm of the Federal University of Technology Akure, Ondo State, Nigeria. The soil at Akure is an Alfisol classified as clayey Skeletal Kaolinitic isohyperthermic Oxic Paleustalf or ferric Luvisol. Each year, the experiment was conducted to assess the effect of six levels $(0,2,4,6,8$, and $10 \mathrm{t} / \mathrm{ha})$ of cow dung on soil physical properties, growth and yield of maize (Zea mays). The 6 treatments were arranged in a randomized complete block design and replicated four times. Results show that application of cow dung increased porosity, moisture content, infiltration rate and maize growth and yield and reduced bulk density, soil temperature and soil dispersion ratio compared with no application of manure. Increasing levels of cow dung from $0-10$ t/ha improve these physical properties and maize yield. Application of $10 \mathrm{t} / \mathrm{ha}$ cow dung increased the weight of dry grains of maize by $115,79,75,65$ and $49 \%$ compared with $0,2,4,6$ and 8 t/ha cow dung respectively. Increased total porosity associated with reduction in soil bulk density was found in this study to result in increased water infiltration and retention leading to reduction in soil temperature and higher maize yield. Therefore regular addition organic matter in forms of manure should be an integral management plan of tropical Alfisol to enhance infiltration rate, reduce bulk density and increase crop performance.

(c) 2016 PSCI Publisher All rights reserved.
\end{abstract}

Key words: Bulk density; dispersion ratio; infiltration rate; moisture content; organic matter; porosity

\section{Introduction}

Maize (Zea mays) was introduced into Africa in the 1500s and has since become one of Africa's dominant food crops and an important stable food for more than 1.2 billion people in sub-Saharan Africa and Latin America (IITA 2012). It is consumed as a vegetable, although it is a grain crop. The grains are rich in vitamin A, C and E, carbohydrate and essential minerals, and contain $9 \%$ protein. They are also rich in dietary fibre and calories which are a good source of energy (IITA 2012). Production figures from FAO (FAOSTAT 2011) show that the area planted to maize in Nigeria has increased from 438,000 ha in 1981 to $3,335,860$ ha in 2009 with associated increase in production from 720 , 000 tons to $7,338,840$ tons during the same period. The demand for maize sometimes outstrips supply as a result of the various domestic uses (Akande 1994). Increase in crop production is desirable in order to cater for ever increasing population growth which subsequently demands for more food production. The present trend on sustained agriculture requires successful soil resource management geared toward better crop production. There is therefore need to study the effect of soil management practices that can influence soil water, temperature and density and influence maize yield. These practices include organic manuring. Application of organic manure influences soil properties such as temperature, moisture content, bulk density, porosity and infiltration (Bullock and Burton 1996; Hullugalle et al. 1986; Obi and Ebo 1995). Use of organic manure has shown imprints on soil physical properties. Addition of poultry manure was found to increase soil organic matter content. Many reports have shown that this resulted in increased water holding capacity, porosity, infiltration capacity, hydraulic conductivity and water stable aggregate and decreased bulk density and surface crusting (Haynes and Naidil 1998). Obi and Ebo (1995) observed that there was a significant decrease in soil dry bulk density under organic manure plot. The relative reduction in bulk density of soil with organic fertilizer over the control was $9.1 \%$.

However, the effect of organic manure in influencing soil physical properties and therefore crop yield depends on type of soil, manure, ecology and crop. There is scanty information on cow dung requirement of maize in humid tropical Alfisol of Nigeria and implication on maize performance and soil physical conditions. This work studied the impact of cow dung on selected soil physical properties, growth and yield of maize. The study is expected to provide information on soil management requirement of maize. 


\section{Material And Methods}

Field experiments were carried out during the early cropping seasons of 2014 and 2015 at the Teaching and Research Farm of the Federal University of Technology Akure, Ondo State, Nigeria. The University is located on $7^{\circ} 15^{\prime} \mathrm{N}$, $5^{\circ} 15^{\prime} \mathrm{E}$ in the rain forest zone of southwest Nigeria. The soil at Akure is an Alfisol classified as clayey Skeletal Kaolinitic isohyperthermic Oxic Paleustalf or ferric Luvisol (FAO, 1998). There are two rainy season, one from March to July and the other from mid-August to November, with temperature ranging from 24 to $32^{\circ} \mathrm{C}$ and annual rainfall in Akure is about $1500 \mathrm{~mm}$. The predominant weeds at the site of the experiment were siam weed (Chromolaena odorata L. King and Robinson), haemorrhage plant (Aspilia africana Pers. Adam) and broom weed (Sida acuta Burm). The surface soil of the experimental site was sandyloam with 60.0, 22.2 and $17.8 \%$ sand, silt and clay, respectively. The bulk density was 1.65 $\mathrm{g} / \mathrm{cm}^{3}$ and porosity of $37.7 \%$. The value for organic matter, total $\mathrm{N}$, available $\mathrm{P}$, exchangeable $\mathrm{K}, \mathrm{Ca}, \mathrm{Mg}$ and $\mathrm{pH}$ were 2.8 $\%, 0.15 \%, 10.3 \mathrm{mg} / \mathrm{kg}, 0.16 \mathrm{cmol} / \mathrm{kg}, 1.51 \mathrm{cmol} / \mathrm{kg}, 0.50 \mathrm{cmol} / \mathrm{kg}$ and 6.5 respectively. The same location was used for the 2014 and 2015 cropping of maize.

Each year, the experiment was conducted to assess the effect of six levels $(0,2,4,6,8$, and 10 t/ha) of cow dung on soil physical properties, growth and yield of maize. The 6 treatments were arranged in a randomized complete block design and replicated four times.

\section{Land preparation and crop establishment}

Land preparation was done by ploughing and harrowing. Plot size was $3 \times 2 \mathrm{~m}$. Plots were separated by $1 \mathrm{~m}$ apart and block $1 \mathrm{~m}$ apart. The cow dung at the rate $0,2,4,6,8$, and $10 \mathrm{t} /$ ha was applied to the soil surface immediately after land preparation in March and left for two weeks before planting to allow for mineralization. Maize was planted early April each year. Akure local variety of maize was planted with 2 seeds per hole at a spacing of 75 x $25 \mathrm{~cm}$ and later thinned to 1 plant per hole to give a plant population of 53,333 plants per ha two weeks after germination. Weeds were controlled manually at 3 and 8 weeks after planting.

\section{Determination of soil properties and chemical analysis of cow dung used for the experiments}

'Before the start of the experiment in 2014, soil samples were collected from 10 points randomly from the site. The soil samples were mixed, air-dried and passed through a 2-mm sieve before determination. Soil organic matter was determined by Walkley and Black sulphuric acid-dichromate digestion followed by back titration with ferrous ammonium sulphate (Nelson and Sommers 1996). Total $\mathrm{N}$ was determined by digestion of $0.3 \mathrm{~g}$ of the soil sample in a mixture of Se, $\mathrm{LiSO}_{4}, \mathrm{H}_{2} \mathrm{O}_{2}$ and concentrated $\mathrm{H}_{2} \mathrm{SO}_{4}$ (Anderson and Ingram, 1993). The $\mathrm{N}$ content in the digest was determined colorimetrically. Available $\mathrm{P}$ was determined by the Olsen method as described by Okelabo et al. (2002). The basic cations $(\mathrm{K}, \mathrm{Ca}$ and $\mathrm{Mg}$ ) were extracted by leaching $5 \mathrm{~g}$ of soil sample with $50 \mathrm{ml}$ ammonium acetate at $\mathrm{pH} 7$ (Anderson and Ingram 1993). The exchangeable $\mathrm{K}$ in the extract was determined with flame photometer, and $\mathrm{Ca}$ and $\mathrm{Mg}$ were determined using an absorption spectrophotometer. Soil $\mathrm{pH}$ was determined using a glass $\mathrm{pH}$ meter at a 1:2 soil / water ratio. Undisturbed samples were collected from the site using steel coring tubes $(0.04 \mathrm{~m}$ diameter, $0.01 \mathrm{~m}$ high $)$ and were put in an oven set at $100^{\circ} \mathrm{C}$ for $24 \mathrm{~h}$ for determination of bulk density and porosity was calculated using the particle density of $2.65 \mathrm{~g} / \mathrm{cm}^{3}$. Particle size analysis was done using the hydrometer method (Gee and Bauder 1996).

The cow dung used for the experiment was obtained from the Research farm of the University. The manure was processed to allow decomposition. It was stacked under a shed for 1 week to allow quick mineralization. About $2 \mathrm{~g}$ subsamples of the cow dung was analysed to determine their nutrient composition. The samples were air-dried and crushed to pass through a 2-mm sieve before analysis. The samples were analysed for organic $\mathrm{C}$, total $\mathrm{N}, \mathrm{P}, \mathrm{K}, \mathrm{Ca}$ and $\mathrm{Mg}$. The percentage organic carbon was determined by the Walkely and Black procedure using the dichromate wet oxidation method, total $\mathrm{N}$ was determined by micro-Kjeldahl digestion, followed by distillation and titration while the determination of other nutrients such as $\mathrm{P}, \mathrm{K}, \mathrm{Ca}$ and $\mathrm{Mg}$ was done using the wet digestion method based on $25-5-5 \mathrm{~mL}^{-} \mathrm{HNO}_{3}-\mathrm{H}_{2} \mathrm{SO}_{4}-$ $\mathrm{HClO}_{4}$ acids (Horwitz, 1997). Phosphorus was measured colorimetrically by the molybdate blue method in an autoanalyser, $\mathrm{K}$ by flame photometry, and $\mathrm{Ca}$ and $\mathrm{Mg}$ by atomic absorption spectrophotometer.

\section{Determination of soil physical properties}

Three weeks after planting maize in each year, determination of selected soil physical properties in all plots commenced and this was done at 3 weeks intervals on four occasions for each crop of maize. Five undisturbed sample were collected at $0-0.10 \mathrm{~m}$ depth from each plot using a steel coring tube and were used to evaluate bulk density, porosity and gravimetric moisture content as described above. Soil temperature was determined at $15.00 \mathrm{~h}$ with soil thermometer inserted to $0.1 \mathrm{~m}$ depth. Dispersion ratio was done by determining the amounts of silt and clay in calgon-dispersed as well as water-dispersed samples using Bouyoucos hydrometer method of particle size analysis described by Gee and Bauder (1986). Dispersion ratio was determined as a measure of aggregate stability using the formula

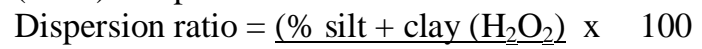

(\% silt + clay (calgon)

Infiltration of water into the soil was determined in the experimental field using a double ring infiltrometer (Bouwer 1986), with a $30 \mathrm{~cm}$ inner diameter and $60 \mathrm{~cm}$ outer diameter cylinder inserted $10 \mathrm{~cm}$ into the soil at the 
experimental plots. Water entering the soil was measured with a calibrated Marriott bottle. A constant water head of 20 $\mathrm{mm}$ was maintained in both rings.

\section{Growth and yield parameters}

Ten plants were selected per plot for observations. Plant heights, stem girth, number of leaves and leaf area/ plant were taken at 9 weeks after planting. Plant height was taken by using meter rule, stem girth by the use of vernier calliper, number of leaves by counting and leaf are was calculated using the formula

LA = L x W x A (Dwyer and Steward, 1986)

Where LA = leaf area $\left(\mathrm{cm}^{3}\right)$

$\mathrm{L}=$ leaf length $(\mathrm{cm})$

$\mathrm{W}=$ leaf maximum width $(\mathrm{cm})$

$\mathrm{A}=$ constant $=0.75$

Yield parameters such as fresh cob weight, weight of wet grains and weight of dry grains were collected after harvesting Statistical analysis

Data collected were subjected to analysis of variance test and treatment means were compared using the Duncan's multiple range test $(\mathrm{DMRT})$ at $\mathrm{p}=0.05$

\section{Results}

Initial soil fertility status of the site and chemical analysis of cow dung used for the experiments

The soil at the site was sandy loam in texture. The soil was low in organic matter, $\mathrm{N}, \mathrm{Ca}$ and $\mathrm{Mg}$ whereas $\mathrm{P}$ and $\mathrm{K}$ were adequate (Akinrinde and Obigbesan 2000). The site also had high bulk density. The results of the chemical analysis of the cow dung used for the experiments (2014 and 2015) are presented in Table 1. The results show that it contains nutrient elements $(\mathrm{N}, \mathrm{P}, \mathrm{K}, \mathrm{Ca}$ and $\mathrm{Mg}$ ) required for the growth of cereal crop like maize. The organic carbon was the highest while $\mathrm{K}$ was the least

Table 1: Chemical composition of cow dung used for the experiments

\begin{tabular}{lll}
\hline Property & 2014 & 2015 \\
\hline Organic carbon (\%) & 25.6 & 26.1 \\
Nitrogen (\%) & 1.88 & 1.86 \\
C:N & 13.6 & 14.0 \\
Phosphorous (\%) & 0.91 & 0.89 \\
Potassium (\%) & 0.41 & 0.43 \\
Calcium (\%) & 5.10 & 5.40 \\
Magnesium (\%) & 2.40 & 2.44 \\
\hline
\end{tabular}

Table 2. Effect of cow dung on soil bulk density at 3, 6,9 and 12 WAP of maize cropping in 2014 and 2015

\begin{tabular}{llllllllll}
\hline $\begin{array}{l}\text { Cow dung rates } \\
(\mathrm{t} / \mathrm{ha})\end{array}$ & $\begin{array}{l}\text { Bulk } \\
\left(\mathrm{g} / \mathrm{cm}^{3}\right)\end{array}$ & density & $\begin{array}{l}\text { Bulk } \\
\left(\mathrm{g} / \mathrm{cm}^{3}\right)\end{array}$ & density & $\begin{array}{l}\text { Bulk } \\
\left(\mathrm{g} / \mathrm{cm}^{3}\right)\end{array}$ & $\begin{array}{l}\text { density } \\
6 \mathrm{WAP}\end{array}$ & $\begin{array}{l}\text { Bulk } \\
\left(\mathrm{g} / \mathrm{cm}^{3}\right)\end{array}$ & $\begin{array}{l}\text { density } \\
12 \mathrm{WAP}\end{array}$ \\
\hline & $3 \mathrm{WAP}$ & & 2015 & Mean & 2015 \\
0 & 2014 & 2015 & 2014 & 2015 & 2014 & 2015 & 2014 & 2015 \\
2 & $1.51 \mathrm{a}$ & $1.65 \mathrm{a}$ & $1.49 \mathrm{a}$ & $1.65 \mathrm{a}$ & $1.49 \mathrm{a}$ & $1.65 \mathrm{a}$ & $1.49 \mathrm{a}$ & $1.65 \mathrm{a}$ & $1.57 \mathrm{a}$ \\
4 & $1.42 \mathrm{~b}$ & $1.58 \mathrm{~b}$ & $1.41 \mathrm{~b}$ & $1.56 \mathrm{~b}$ & $1.41 \mathrm{~b}$ & $1.56 \mathrm{~b}$ & $1.42 \mathrm{~b}$ & $1.54 \mathrm{~b}$ & $1.49 \mathrm{~b}$ \\
6 & $1.36 \mathrm{c}$ & $1.47 \mathrm{c}$ & $1.36 \mathrm{c}$ & $1.44 \mathrm{c}$ & $1.36 \mathrm{c}$ & $1.44 \mathrm{c}$ & $1.37 \mathrm{c}$ & $1.44 \mathrm{c}$ & $1.41 \mathrm{c}$ \\
8 & $1.27 \mathrm{~d}$ & $1.26 \mathrm{~d}$ & $1.25 \mathrm{~d}$ & $1.24 \mathrm{~d}$ & $1.25 \mathrm{~d}$ & $1.24 \mathrm{~d}$ & $1.25 \mathrm{~d}$ & $1.24 \mathrm{~d}$ & $1.25 \mathrm{~d}$ \\
10 & $1.10 \mathrm{e}$ & $1.17 \mathrm{e}$ & $1.10 \mathrm{e}$ & $1.12 \mathrm{e}$ & $1.10 \mathrm{e}$ & $1.12 \mathrm{e}$ & $1.12 \mathrm{e}$ & $1.12 \mathrm{e}$ & $1.12 \mathrm{e}$ \\
\hline
\end{tabular}

Values followed by similar letters under the same column are not significantly different at $\mathrm{p}=0.05$ according to Duncan's multiple range test $(\mathrm{DMRT}), \mathrm{WAP}=$ weeks after planting

Table 3. Effect of cow dung on soil total porosity at 3, 6,9 and 12 WAP of maize cropping in 2014 and 2015

\begin{tabular}{|c|c|c|c|c|c|c|c|c|c|}
\hline \multirow[t]{2}{*}{$\begin{array}{l}\text { Cow dung rates } \\
(\mathrm{t} / \mathrm{ha})\end{array}$} & \multicolumn{2}{|c|}{$\begin{array}{l}\text { Porosity (\%) } \\
3 \text { WAP }\end{array}$} & \multicolumn{2}{|c|}{$\begin{array}{l}\text { Porosity (\%) } \\
6 \text { WAP }\end{array}$} & \multicolumn{2}{|c|}{$\begin{array}{l}\text { Porosity (\%) } \\
9 \text { WAP }\end{array}$} & \multicolumn{2}{|c|}{$\begin{array}{l}\text { Porosity (\%) } \\
12 \text { WAP }\end{array}$} & \multirow[t]{2}{*}{ Mean } \\
\hline & 2014 & 2015 & 2014 & 2015 & 2014 & 2015 & 2014 & 2015 & \\
\hline 0 & $37.7 \mathrm{e}$ & $43.0 \mathrm{f}$ & $37.7 \mathrm{f}$ & $43.8 \mathrm{f}$ & $37.7 \mathrm{f}$ & $43.8 \mathrm{f}$ & $37.7 \mathrm{f}$ & $43.8 \mathrm{f}$ & $40.7 \mathrm{f}$ \\
\hline 4 & $40.5 \mathrm{~d}$ & $48.7 \mathrm{de}$ & $45.7 \mathrm{~d}$ & $48.7 \mathrm{~d}$ & $45.7 \mathrm{~cd}$ & $48.7 d$ & $45.3 \mathrm{~cd}$ & $48.3 d$ & $46.7 \mathrm{~d}$ \\
\hline 6 & $51.9 \mathrm{c}$ & $52.1 \mathrm{c}$ & $53.2 \mathrm{c}$ & $52.8 \mathrm{c}$ & $53.2 \mathrm{c}$ & $52.8 \mathrm{c}$ & $52.8 \mathrm{c}$ & $52.8 \mathrm{c}$ & $52.8 \mathrm{c}$ \\
\hline 8 & $55.8 \mathrm{~b}$ & $58.5 b$ & $57.7 \mathrm{~b}$ & $58.5 \mathrm{~b}$ & $57.7 b$ & $58.5 \mathrm{~b}$ & $57.4 \mathrm{~b}$ & $57.7 \mathrm{~b}$ & $57.7 \mathrm{~b}$ \\
\hline
\end{tabular}

Values followed by similar letters under the same column are not significantly different at $\mathrm{p}=0.05$ according to Duncan's multiple range test $(\mathrm{DMRT}), \mathrm{WAP}=$ weeks after planting

\section{Effect of cow dung on soil physical properties}

Data on the effect of cow dung on soil bulk density, total porosity, moisture content and temperature are shown respectively on Tables 2, 3, 4and 5. Application of cow dung to crops of maize including the mean from 2 t/ha significantly $(\mathrm{p}=0.05)$ reduced soil bulk density and temperature and increased soil moisture content and total porosity 
compared with the control (no application of cow dung). Increasing levels of cow dung from $0-10$ t/ha reduced soil bulk density and increased total porosity of the soil. Moisture content was also increased with cow dung up to 10 t/ha. However, using the mean of all sampling periods, there were no significant differences between the moisture content 0 and $2 \mathrm{t} / \mathrm{ha}$ and 8 and $10 \mathrm{t} /$ ha cow dung levels. Increasing levels of cow dung reduced soil temperature. Soil temperature between the mean of 2 and $4 \mathrm{t}$ ha cow dung were not significant. The least soil temperature was recorded by 10 t/ha cow dung.

Table 4. Effect of cow dung on soil moisture content at 3, 6, 9 and 12 WAP of maize cropping in 2014 and 2015

\begin{tabular}{|c|c|c|c|c|c|c|c|c|c|}
\hline \multirow[t]{2}{*}{$\begin{array}{l}\text { Cow dung rates } \\
\text { (t /ha) }\end{array}$} & \multicolumn{2}{|c|}{$\begin{array}{l}\text { Moisture content (\%) } \\
3 \text { WAP }\end{array}$} & \multirow{2}{*}{$\begin{array}{l}\text { Moisture } \\
(\%) \\
6 \text { WAP } \\
2014\end{array}$} & content & \multicolumn{2}{|c|}{$\begin{array}{l}\text { Moisture content (\%) } \\
9 \text { WAP }\end{array}$} & \multicolumn{2}{|c|}{$\begin{array}{l}\text { Moisture content (\%) } \\
12 \text { WAP }\end{array}$} & Mean \\
\hline & 2014 & 2015 & & 2015 & 2014 & 2015 & 2014 & 2015 & \\
\hline 0 & $15.2 \mathrm{e}$ & $16.1 \mathrm{e}$ & $15.9 \mathrm{f}$ & $15.8 \mathrm{e}$ & $17.0 \mathrm{~d}$ & $15.9 \mathrm{e}$ & $17.1 \mathrm{~d}$ & $16.0 \mathrm{e}$ & $16.1 \mathrm{~d}$ \\
\hline 2 & $16.3 \mathrm{~d}$ & $17.2 \mathrm{~d}$ & $16.7 \mathrm{e}$ & $17.2 \mathrm{~d}$ & $18.4 \mathrm{c}$ & $17.3 \mathrm{~d}$ & $18.4 \mathrm{c}$ & 17.4 & $17.4 \mathrm{bc}$ \\
\hline 4 & $17.1 \mathrm{~d}$ & $17.6 \mathrm{c}$ & $17.9 \mathrm{~d}$ & $17.5 \mathrm{c}$ & $18.8 b c$ & $17.7 \mathrm{c}$ & $18.7 \mathrm{bc}$ & 17.7 & $17.9 \mathrm{~b}$ \\
\hline 6 & $17.7 \mathrm{~cd}$ & $17.7 \mathrm{~b}$ & $18.8 \mathrm{c}$ & $17.8 \mathrm{~b}$ & $18.9 \mathrm{ab}$ & $17.8 \mathrm{~b}$ & $18.9 \mathrm{ab}$ & $17.9 \mathrm{~b}$ & $18.2 \mathrm{bc}$ \\
\hline 8 & $18.8 \mathrm{~b}$ & $17.8 \mathrm{~b}$ & $19.8 \mathrm{~b}$ & $18.1 \mathrm{a}$ & $19.2 \mathrm{a}$ & $18.2 \mathrm{a}$ & $19.2 \mathrm{a}$ & $18.2 \mathrm{a}$ & $18.7 \mathrm{ab}$ \\
\hline 10 & $19.9 \mathrm{a}$ & $18.1 \mathrm{a}$ & $20.5 \mathrm{a}$ & $18.1 \mathrm{a}$ & $19.3 \mathrm{a}$ & $18.4 \mathrm{a}$ & $19.4 \mathrm{a}$ & $18.3 \mathrm{a}$ & $19.0 \mathrm{a}$ \\
\hline
\end{tabular}

Values followed by similar letters under the same column are not significantly different at $\mathrm{p}=0.05$ according to Duncan's multiple range test $(\mathrm{DMRT}), \mathrm{WAP}=$ weeks after planting

Table 5. Effect of cow dung on soil temperature at 3, 6,9 and 12 WAP of maize cropping in 2014 and 2015

\begin{tabular}{llllllllll}
\hline $\begin{array}{l}\text { Cow dung rates } \\
(\mathrm{t} / \mathrm{ha})\end{array}$ & $\begin{array}{l}\text { Soil temperature }\left({ }^{\circ} \mathrm{C}\right) \\
3 \text { WAP }\end{array}$ & \multicolumn{2}{l}{$\begin{array}{l}\text { Soil temperature }\left({ }^{\circ} \mathrm{C}\right) \\
6 \mathrm{WAP}\end{array}$} & \multicolumn{3}{l}{$\begin{array}{l}\text { Soil temperature }\left({ }^{\circ} \mathrm{C}\right) \\
9 \text { WAP }\end{array}$} & $\begin{array}{l}\text { Soil } \\
\left({ }^{\circ} \mathrm{C}\right) \\
12 \mathrm{WAP}\end{array}$ \\
\hline & 2014 & 2015 & 2014 & 2015 & 2014 & 2015 & 2014 & 2015 & \\
0 & $38.0 \mathrm{a}$ & $39.3 \mathrm{a}$ & $38.7 \mathrm{a}$ & $38.3 \mathrm{a}$ & $39.9 \mathrm{a}$ & $38.8 \mathrm{a}$ & $38.0 \mathrm{a}$ & $39.7 \mathrm{a}$ & $38.9 \mathrm{a}$ \\
2 & $37.1 \mathrm{bc}$ & $38.2 \mathrm{bc}$ & $37.9 \mathrm{bc}$ & $36.9 \mathrm{bc}$ & $38.1 \mathrm{~b}$ & $37.1 \mathrm{~b}$ & $37.4 \mathrm{~b}$ & $38.2 \mathrm{~b}$ & $37.6 \mathrm{bc}$ \\
4 & $37.7 \mathrm{c}$ & $37.5 \mathrm{c}$ & $37.6 \mathrm{c}$ & $36.0 \mathrm{c}$ & $37.7 \mathrm{bc}$ & $36.0 \mathrm{c}$ & $37.0 \mathrm{~b}$ & $37.5 \mathrm{c}$ & $37.1 \mathrm{c}$ \\
6 & $37.5 \mathrm{c}$ & $37.1 \mathrm{~cd}$ & $37.5 \mathrm{c}$ & $35.1 \mathrm{~d}$ & $37.1 \mathrm{c}$ & $35.1 \mathrm{~d}$ & $36.2 \mathrm{c}$ & $36.1 \mathrm{~d}$ & $36.4 \mathrm{~d}$ \\
8 & $37.2 \mathrm{~cd}$ & $36.8 \mathrm{de}$ & $36.1 \mathrm{c}$ & $34.1 \mathrm{e}$ & $36.8 \mathrm{~cd}$ & $34.2 \mathrm{e}$ & $35.5 \mathrm{~d}$ & $35.4 \mathrm{e}$ & $35.7 \mathrm{e}$ \\
10 & $36.3 \mathrm{~d}$ & $36.1 \mathrm{e}$ & $35.8 \mathrm{~d}$ & $32.9 \mathrm{f}$ & $36.0 \mathrm{~d}$ & $33.0 \mathrm{f}$ & $34.3 \mathrm{e}$ & $34.2 \mathrm{f}$ & $34.8 \mathrm{f}$ \\
\hline
\end{tabular}

Values followed by similar letters under the same column are not significantly different at $\mathrm{p}=0.05$ according to Duncan's multiple range test $(\mathrm{DMRT}), \mathrm{WAP}=$ weeks after planting

Data on the effect of cow dung on soil dispersion ratio and infiltration rate on maize produced at Akure at 3, 6, 9, 12 weeks after planting (WAP) in 2014 and 2015 and the means are shown in Tables 6 and 7. Application of cow dung significantly reduced dispersion ratio compared with the control. There was no significant difference between 0 and $2 \mathrm{t} / \mathrm{ha}$ at 3 WAP in both 2014 and 2015 crops of maize. Increasing levels of cow dung from 0-10 t/ha reduced the dispersion ratio. The least soil dispersion ratio was recorded by $10 \mathrm{t} /$ ha cow dung. Application of cow dung from 2 t/ha increased soil infiltration rate compared with the control (Table 7) at all sampling periods and the mean. Increasing the cow dung levels from $0-10$ t/ha increased infiltration rate

Table 6. Effect of cow dung on soil dispersion ratio at 3, 6, 9 and 12 WAP of maize cropping in 2014 and 2015

\begin{tabular}{lllllllllll}
\hline $\begin{array}{l}\text { Cow } \\
\text { (t/ha) }\end{array}$ & dung & rates & Dispersion ratio (\%) & \multicolumn{2}{l}{ Dispersion ratio (\%) } & Dispersion ratio (\%) & Dispersion ratio (\%) & Mean \\
\hline & 2014 & 2015 & 2014 & 2015 & 2014 & 2015 & 2014 & 2015 & \\
0 & $67 \mathrm{a}$ & $73 \mathrm{a}$ & $67 \mathrm{a}$ & $67 \mathrm{a}$ & $68 \mathrm{a}$ & $67 \mathrm{a}$ & $66 \mathrm{a}$ & $65 \mathrm{a}$ & $68 \mathrm{a}$ \\
2 & & $66 \mathrm{a}$ & $72 \mathrm{a}$ & $62 \mathrm{~b}$ & $62 \mathrm{~b}$ & $58 \mathrm{~b}$ & $62 \mathrm{~b}$ & $58 \mathrm{~b}$ & $60 \mathrm{~b}$ & $62 \mathrm{bc}$ \\
4 & $65 \mathrm{a}$ & $70 \mathrm{bc}$ & $59 \mathrm{c}$ & $59 \mathrm{bc}$ & $57 \mathrm{c}$ & $59 \mathrm{c}$ & $56 \mathrm{c}$ & $58 \mathrm{c}$ & $60 \mathrm{~cd}$ \\
6 & & $63 \mathrm{a}$ & $69 \mathrm{bc}$ & $57 \mathrm{c}$ & $56 \mathrm{c}$ & $57 \mathrm{c}$ & $53 \mathrm{~cd}$ & $56 \mathrm{c}$ & $56 \mathrm{c}$ & $58 \mathrm{~d}$ \\
8 & $62 \mathrm{a}$ & $68 \mathrm{c}$ & $50 \mathrm{~d}$ & $51 \mathrm{~d}$ & $49 \mathrm{~d}$ & $48 \mathrm{~d}$ & $48 \mathrm{~d}$ & $51 \mathrm{~d}$ & $53 \mathrm{e}$ \\
10 & $62 \mathrm{a}$ & $61 \mathrm{~d}$ & $51 \mathrm{~d}$ & $42 \mathrm{e}$ & $48 \mathrm{~d}$ & $43 \mathrm{e}$ & $46 \mathrm{~d}$ & $44 \mathrm{e}$ & $49 \mathrm{f}$ \\
\hline
\end{tabular}

Values followed by similar letters under the same column are not significantly different at $\mathrm{p}=0.05$ according to Duncan's multiple range test $(\mathrm{DMRT}), \mathrm{WAP}=$ weeks after planting

Table 7. Effect of cow dung on soil infiltration rate at 2, 4 and 6 WAP of maize cropping in 2014 and 2015

\begin{tabular}{llllllll}
\hline $\begin{array}{l}\text { Cow dung } \\
\text { rates } \\
(\mathrm{t} / \mathrm{ha})\end{array}$ & $\begin{array}{l}\text { Infiltration } \\
\text { 2WAP }\end{array}$ & rate $(\mathrm{cm} / \mathrm{hr})$ & $\begin{array}{l}\text { Infiltration } \\
\text { 4WAP }\end{array}$ & rate $(\mathrm{cm} / \mathrm{hr})$ & $\begin{array}{l}\text { Infiltration } \\
\text { 6WAP }\end{array}$ & & \\
\hline & 2014 & 2015 & 2014 & 2015 & 2014 & 2015 & Mean \\
0 & $11.5 \mathrm{f}$ & $13.3 \mathrm{f}$ & $11.9 \mathrm{f}$ & $12.5 \mathrm{f}$ & $13.6 \mathrm{e}$ & $12.7 \mathrm{f}$ & $12.6 \mathrm{f}$ \\
2 & $14.1 \mathrm{e}$ & $18.2 \mathrm{e}$ & $17.1 \mathrm{e}$ & $14.3 \mathrm{e}$ & $14.3 \mathrm{~d}$ & $13.2 \mathrm{e}$ & $15.2 \mathrm{e}$ \\
4 & $15.9 \mathrm{de}$ & $25.2 \mathrm{~d}$ & $17.3 \mathrm{de}$ & $23.6 \mathrm{~d}$ & $25.8 \mathrm{c}$ & $24.2 \mathrm{~d}$ & $22.0 \mathrm{~d}$ \\
6 & $16.0 \mathrm{~cd}$ & $27.0 \mathrm{c}$ & $24.8 \mathrm{c}$ & $24.1 \mathrm{~cd}$ & $32.7 \mathrm{~b}$ & $24.6 \mathrm{~cd}$ & $24.9 \mathrm{c}$ \\
8 & $28.2 \mathrm{~b}$ & $30.3 \mathrm{~b}$ & $25.9 \mathrm{~b}$ & $31.4 \mathrm{~b}$ & $34.5 \mathrm{a}$ & $31.5 \mathrm{~b}$ & $30.3 \mathrm{~b}$ \\
10 & $30.9 \mathrm{a}$ & $33.1 \mathrm{a}$ & $31.5 \mathrm{a}$ & $35.0 \mathrm{a}$ & $35.8 \mathrm{a}$ & $32.4 \mathrm{a}$ & $33.1 \mathrm{a}$ \\
\hline
\end{tabular}

Values followed by similar letters under the same column are not significantly different at $\mathrm{p}=0.05$ according to Duncan's multiple range test $(\mathrm{DMRT}), \mathrm{WAP}=$ weeks after planting 


\section{Effect of cow dung on the performance of maize}

Data on the effect of cow dung on the growth and yield parameters of maize are presented on Tables 8 and 9 respectively. Application of cow dung increased the growth and yield parameters of maize significantly ( $\mathrm{p}=0.05$ ) compared with the control. However, plant girth, leaf area and number of leaves in 2014 and 2015 crops of maize do not give any significant different between 0 and 2 t/ha cow dung. Increasing cow dung level from $0-10$ t/ha increased the growth and yield parameters of maize significantly with $10 \mathrm{t} /$ ha having the highest value. Using the mean, application of $10 \mathrm{t} /$ ha cow dung increased the weight of dry grains of maize by $115,79,75,65$ and $49 \%$ compared with the control, 2,4 , 6 and 8 t/ha cow dung respectively

Table 8. Effect of cow dung on the growth of maize in 2014 and 2015

\begin{tabular}{|c|c|c|c|c|c|c|c|c|c|c|c|c|}
\hline \multirow[t]{2}{*}{$\begin{array}{l}\text { Cow dung } \\
\text { rates } \\
(\mathrm{t} / \mathrm{ha}) \\
\end{array}$} & \multicolumn{3}{|c|}{$\begin{array}{l}\text { Plant height } \\
(\mathrm{cm})\end{array}$} & \multicolumn{3}{|c|}{$\begin{array}{l}\text { Plant girth } \\
(\mathrm{cm})\end{array}$} & \multicolumn{3}{|l|}{$\begin{array}{l}\text { Leaf area } \\
\left(\mathrm{cm}^{2}\right)\end{array}$} & \multicolumn{3}{|c|}{$\begin{array}{l}\text { Number of } \\
\text { leaves/plant }\end{array}$} \\
\hline & 2014 & 2015 & Mean & 2014 & 2015 & mean & 2014 & 2015 & Mean & 2014 & 2015 & Mean \\
\hline 0 & $135.5 \mathrm{e}$ & $107.5 \mathrm{e}$ & $121.5 \mathrm{f}$ & $8.9 \mathrm{c}$ & $7.6 \mathrm{c}$ & $8.3 c$ & $421.9 \mathrm{c}$ & $464.6 \mathrm{~d}$ & $443.1 \mathrm{f}$ & $12.0 \mathrm{~b}$ & $11.3 \mathrm{~b}$ & $11.7 \mathrm{~b}$ \\
\hline 2 & $209.4 d$ & $168.5 \mathrm{~d}$ & $188.9 \mathrm{e}$ & $9.0 \mathrm{c}$ & $7.8 \mathrm{c}$ & $8.4 \mathrm{c}$ & $504.6 \mathrm{c}$ & $613.0 \mathrm{~cd}$ & $558.8 \mathrm{e}$ & $12.6 b$ & $11.6 \mathrm{ab}$ & $12.1 \mathrm{ab}$ \\
\hline 4 & $241.0 \mathrm{c}$ & $185.2 \mathrm{c}$ & 213.1d & $9.6 b c$ & $7.9 \mathrm{c}$ & $8.7 \mathrm{c}$ & $519.3 \mathrm{c}$ & 660.3 & 589.8de & $12.6 b$ & $11.6 a b$ & $12.1 \mathrm{ab}$ \\
\hline 6 & 245.3 & $190.5 \mathrm{c}$ & $217.9 \mathrm{~cd}$ & $10.3 b$ & $8.3 b c$ & $9.3 \mathrm{bc}$ & $710.2 \mathrm{ab}$ & $821.0 \mathrm{bc}$ & $765.6 \mathrm{c}$ & $13.0 \mathrm{ab}$ & $12.0 \mathrm{a}$ & $12.5 \mathrm{ab}$ \\
\hline 8 & 295.2 & $199.4 b c$ & $247.3 b$ & $11.7 \mathrm{a}$ & $9.6 \mathrm{ab}$ & $10.7 \mathrm{ab}$ & $787.8 \mathrm{~b}$ & $846.5 b$ & $817.1 \mathrm{bc}$ & $13.0 \mathrm{ab}$ & $12.3 \mathrm{a}$ & $12.7 \mathrm{a}$ \\
\hline 10 & 318.6 & $222.7 \mathrm{a}$ & $270.6 a$ & $12.1 \mathrm{a}$ & $10.0 \mathrm{a}$ & $11.1 \mathrm{a}$ & $953.9 \mathrm{a}$ & $975.1 \mathrm{a}$ & $964.5 \mathrm{a}$ & $13.3 \mathrm{a}$ & $12.3 \mathrm{a}$ & $12.8 \mathrm{a}$ \\
\hline
\end{tabular}

Values followed by similar letters under the same column are not significantly different at $\mathrm{p}=0.05$ according to Duncan's multiple range test $(\mathrm{DMRT}), \mathrm{WAP}=$ weeks after planting

Table 9. Effect of cow dung on the yield of maize in 2014 and 2015

\begin{tabular}{|c|c|c|c|c|c|c|c|c|c|}
\hline \multirow{2}{*}{$\begin{array}{l}\text { Cow dung } \\
\text { rates } \\
(\mathrm{t} / \mathrm{ha}) \\
\end{array}$} & \multicolumn{3}{|c|}{$\begin{array}{l}\text { Weight of cob/ plant } \\
(\mathrm{g})\end{array}$} & \multicolumn{3}{|c|}{$\begin{array}{l}\text { Weight of wet grains/plant } \\
\text { (g) }\end{array}$} & \multicolumn{3}{|c|}{ Weight of dry grains/plant (g) } \\
\hline & 2014 & 2015 & mean & 2014 & 2015 & mean & 2014 & 2015 & Mean \\
\hline 0 & $178.9 \mathrm{~d}$ & $155.4 d$ & $167.1 \mathrm{f}$ & $113.9 \mathrm{e}$ & $88.4 \mathrm{e}$ & $101.2 \mathrm{f}$ & $52.7 \mathrm{~d}$ & $44.8 \mathrm{c}$ & $48.8 \mathrm{e}$ \\
\hline 2 & $226.6 \mathrm{~d}$ & $195.4 \mathrm{c}$ & $211.0 \mathrm{e}$ & $146.6 \mathrm{~d}$ & $122.8 \mathrm{~d}$ & $134.7 \mathrm{e}$ & $63.0 \mathrm{c}$ & $53.9 b$ & $58.5 \mathrm{~d}$ \\
\hline 4 & $266.8 \mathrm{c}$ & $233.4 \mathrm{c}$ & $250.1 d$ & $159.2 \mathrm{~cd}$ & $148.7 \mathrm{c}$ & $154.0 \mathrm{~d}$ & $63.1 \mathrm{c}$ & $56.4 \mathrm{~b}$ & $59.8 \mathrm{~d}$ \\
\hline 6 & $311.3 b$ & $282.9 b$ & $297.1 \mathrm{c}$ & $173.5 \mathrm{c}$ & $153.8 b c$ & $163.7 \mathrm{~cd}$ & $68.4 b c$ & $58.3 b$ & $63.4 \mathrm{c}$ \\
\hline 8 & $314.8 \mathrm{~b}$ & $293.9 \mathrm{ab}$ & $304.4 \mathrm{~b}$ & $197.8 b$ & $173.7 b$ & $185.8 b$ & $76.4 b$ & $64.4 \mathrm{~b}$ & $70.4 b$ \\
\hline 10 & $369.0 \mathrm{a}$ & $328.2 \mathrm{a}$ & $348.6 \mathrm{a}$ & $230.0 \mathrm{a}$ & $206.5 \mathrm{a}$ & $218.3 \mathrm{a}$ & $107.1 \mathrm{a}$ & $102.4 \mathrm{a}$ & $104.8 \mathrm{a}$ \\
\hline
\end{tabular}

Values followed by similar letters under the same column are not significantly different at $\mathrm{p}=0.05$ according to Duncan's multiple range test $(\mathrm{DMRT}), \mathrm{WAP}=$ weeks after planting

\section{Discussion}

The cow dung reduced bulk density and temperature and increased moisture content and porosity compared with the control. This was attributed to the enhancement of organic matter by the cow dung. The organic matter should have stabilized soil structure thereby reducing bulk density, increasing porosity and water content. The improvement of these properties with increasing levels of cow dung is adduced to increase soil organic matter (SOM) from the manure. The decrease in bulk density with levels of cow dung could also be as a result of increased microbial activity associated with increased nutrient availability at the rate of manure which could lead to the pulverization of the soil and possibly movement of the heavy clay particle down the soil column. Sommerfeldt and Chang (1995) had earlier found that surface $(0-15 \mathrm{~cm})$ soil bulk density decrease from $0.9 \mathrm{mg} / \mathrm{m}^{3}$ with no manure to $78 \mathrm{mg} / \mathrm{m}^{3}$ with 90 t/ha (wet weight) manure application. The improved soil moisture content with levels of cow dung is adduced to mulching effect of organic manure and improved moisture retention and water acceptance as a result of improved soil structure and macroporosity. Application of cow dung compared with the control reduced dispersion ratio (DR) of the soil. This can also be related to the presence of organic matter in the cow dung compared with no application of manure. The $10 \mathrm{t} / \mathrm{ha}$ cow dung most reduced the DR of the soil. This is related to increase in organic matter from the manure. It is expected that the application of manure would serve to reduce DR and stabilize soil structure since organic matter addition is essential for stabilizing soil against physical degradation and soil erosion. Soils with high DR are weak structurally and can easily be eroded. Many researchers have used this index in predicting soil erosion by water (Igwe et al. 1995)

The infiltration rate of soils depends upon the arrangement of soil particles, porosity and stability of soil aggregates. Also there is inverse relationship between bulk density and infiltration rate of the soil. Soil with 10 t/ha cow dung recorded higher infiltration rate due to better soil particles aggregation, microbial respiration, increased pore spaces and decreased soil bulk density. Similar results regarding the decrease of bulk density and increase infiltration rate as the effect of addition of organic and inorganic fertilizer in soils were reported by Martens and Frankenberger (1992).

The increase in growth and yield parameters of maize in response to the application of cow dung is adduced to the fact that cow dung contains nutrients and these nutrients are released to the soil for maize plant compared with no application of cow dung. Application of cow dung at $10 \mathrm{t} / \mathrm{ha}$ had the highest growth and yield of maize as indicated by least bulk density, soil temperature and DR and highest porosity, moisture content, infiltration rate and increased nutrient availability at the rate of manure. This observation is consistent with the fact that significant negative correlation were 
recorded between fresh cob weight, weight of wet grains and weight of dry grains and bulk density, soil temperature and DR (Table 10). Expectedly, correlation coefficient between porosity, moisture content and infiltration rate and the yield parameters were significantly positive. The best performance of maize under $10 \mathrm{t} / \mathrm{ha}$ cow dung was due to better soil condition resulting from this treatment. These were associated with reduced density, temperature and DR and increased porosity, moisture content and infiltration rate. Increased total porosity associated with reduction in bulk density was found in this study to result in increased water infiltration and retention leading to reduction in soil temperature and therefore better yield. The low performance in the no manure application plots was due to increased bulk density, which is known to reduce root elongation at low water content (Adekiya and Ojeniyi 2002), this will adversely reduce nutrient and water uptake and therefore low yield

Table: 10 Correlation coefficient between mean values of soil physical properties and performance parameters of maize

\begin{tabular}{|c|c|c|c|c|c|c|}
\hline & $\begin{array}{l}\text { Bulk } \\
\text { Density }\end{array}$ & Porosity & Moisture content & Soil temperature & Dispersion ratio & $\begin{array}{l}\text { Infiltration } \\
\text { Rate }\end{array}$ \\
\hline Weight of cob & $-0.975^{* *}$ & $0.974 *$ & $0.907 * *$ & $-0.987 * *$ & $-0.969 * *$ & $0.978 * *$ \\
\hline Weight of wet grain & $-0.969 * *$ & $0.969 * *$ & $0.968 * *$ & $-0.995 * *$ & $-0.996 * *$ & $0.973 * *$ \\
\hline Weight of dry grain & $-0.870^{*}$ & $0.870 *$ & $0.789 *$ & $-0.883^{*}$ & $-0.898 *$ & $0.837 *$ \\
\hline Plant height & $-0.922 * *$ & $0.921 * *$ & $0.996 * *$ & $-0.979 * *$ & $-0.975^{* *}$ & $0.943 * *$ \\
\hline Plant girth & $-0.973 * *$ & $0.973 * *$ & $0.852 *$ & $-0.927 * *$ & $-0.943 * *$ & $0.948 * *$ \\
\hline Leaf area & $-0.990 * *$ & $0.990 * *$ & $0.933 * *$ & $-0.984 * *$ & $-0.975 * *$ & $0.965 * *$ \\
\hline Number of leaves & $-0.976 * *$ & $0.976 * *$ & $0 . .962 * *$ & $-0.971 * *$ & $0.956 * *$ & $0.972 * *$ \\
\hline
\end{tabular}

** Correlation is significant at the 0.01 level

*correlation is significant at the 0.05 level

\section{Conclusion}

Results from the data presented in this study show that application of cow dung increased porosity, moisture content, infiltration rate and better maize growth and yield and reduced bulk density, soil temperature and soil dispersion ratio compared with no application of manure. Increasing levels of cow dung from 0-10 t/ha improve these physical properties and maize yield. Increased total porosity associated with reduction in soil bulk density was found in this study to result in increased water infiltration and retention leading to reduction in soil temperature and higher maize yield. Therefore regular organic matter addition should be an integral management plan of tropical Alfisol to enhance infiltration rate, reduce bulk density and increase maize performance.

\section{References}

"FAOSTAT: Production-Crops 2010 data" 2011. Food and Agricultural Organization of the United Nations.http://faostatfao.org/site/567/DesktopDefault.aspx?PageIZ=567\#ancor

Adekiya AO, Ojeniyi SO. 2002. Evaluation of tomato growth and soil properties under methods of seedling bed preparation in an alfisol in the rainforest zone of southwest Nigeria. Soil and Tillage Research64, 275-279.

Akande SO.1994. Comparative Cost and Return in Maize Production in Nigeria. Nigeria Institute for Social and Economic Research (NISER) Individual Research Project Report, Ibadan: NISER.

Akinrinde EA, Obigbesan GO. 2000. Evaluation of the fertility status of selected soils for crop production in five ecological zones of Nigeria. Proceedings of the $26^{\text {th }}$ Annual Conference of Soil Science Society of Nigeria, Ibadan, Nigeria. Pp. 279-288.

Anderson JM, Ingram JSI. 1993. Tropical soil biology and fertility: a handbook of method. Wallingford (UK): CAB International, 221 pp.

Bouwer H. 1986. Intake rate: cylinder infiltrometer. Pp. 825-844 in Klute A (ed.). Methods of Soil Analysis, Part 1: Physical and Mineralogical Methods, 2 Ed. Madison: American Society of Agronomy and Soil Science Society of America. 1188 p. ISBN 0-89118-088-5

Bullock P, Burton RGO. 1996. Organic manure level and trend in soil of England and Wales. Soil Use and Management 12 (2), $103-104$.

Dwyer LM, Stewart DW. 1986. Leaf area development in field-grown maize. Agronomy Journal78, 334-343.

FAO 1998. World reference base of soil resources. World Soil Resources Report 84. Rome (Italy): Foods and Agriculture Organization of the United Nations

Gee GW, Bauder JW. 1986. Particle size analysis. In: Methods of soil analysis Part 1.Klute, A. (ed.). Monograph No. 9, Am. Soc. Agron. Madison, WI., pp:91-100

Haynes RJ, Naidu R. 1998. Influence of lime fertilizer and manure applications on soil organic matter content and soil physical conditions: A review. Journal of Nutrient Cycling in Agroecosystems 51, 123- 137.

Horwitz W.1997. (Editor), "Official Methods of Analysis of the Association of Official Analytical Chemists International". 16th Edition. AOAC International, Gaithersburg, MD; 1298pp,

Hulugalle NR, Lal R, Terkhile CHH. 1986. Amelioration of soil physical properties by mucuna after mechanized land clearing of a tropical rainforest. Soil Science 141, 219-224.

Igwe CA, Akamgbo FOR, Mbagwu JSC. 1995. Properties of soils of south eastern Nigeria and the role of some aggregating agents in their stability. Soil Science 160: 431-441

IITA 2012. Research to Nourish Africa. International Institute of tropical Agriculture research report. 7-10

Martens DA, Frankenberger WT. 1992. Modification in infiltration rates in an organic amended irrigated soil. Agronomy Journal 84 (4): $707-717$

Nelson DW, Sommers LE. 1992. Total carbon, organic carbon and organic matter In: Page AL, Miller RH, Keeney DR. (Eds.). Methods of Soil Analysis, part 2. ASA, Madison WI, pp. 539- 580.

Obi ME, Ebo PO. 1995. The effect of organic and inorganic amendments on soil physical properties and maize production in severely degraded sandy soil in southern Nigeria. Bioresource Technology 51, 117- 123.

Okalebo JR, Gathua KW, Woomer PL. 1993. Laboratory method of soil and plant Analysis. A working manual. TSB. Soil Science Society of East Africa. Publication No.1, 88pp.

Sommerfeldt TG, Chang C. 1985. Changes in soil properties under annual applications of feed lot manure and different tillage practices. Soil Science Society America Journal 49, 983-987. 